\title{
SYDNEY UNIVERSITY NATURAL RADIOCARBON MEASUREMENTS III
}

\author{
$\mathrm{R}$ GILLESPIE and $\mathrm{R} B$ TEMPLE
}

Sydney University Radiocarbon Laboratory, Department of Physical Chemistry,

University of Sydney, NSW 2006, Australia

This list describes samples dated in this laboratory between November 1972 and December 1974.

Experimental procedures and age calculations are performed by scintillation counting of benzene as previously described (Gillespie and Temple, 1972; 1973) using the group mean values for $\delta^{13} \mathrm{C}$ suggested by Polach (1969) to correct measured $\delta^{14} \mathrm{C}$ values for isotopic fractionation. Sample preparation is as described by Gillespie, Polach and Temple (1972). Ages are based on the Libby value of 5570 years for the half-life of ${ }^{14} \mathrm{C}$.

\section{ACKNOWLEDGMENTS}

We acknowledge with gratitude continued helpful assistance from $\mathrm{H}$ Polach and staff of the Radiocarbon Laboratory, Australian National University, Canberra, ACT, Australia.

Interlaboratory cross checks and duplicates

\begin{tabular}{|c|c|c|c|c|}
\hline Lab no. & SUA date & Other no. & Other date & Ref \\
\hline SUA-4/3 & $590 \pm 70$ & $\mathrm{R} 2553 / 2$ & $675 \pm 40$ & $\begin{array}{l}\text { Rafter (pers } \\
\text { commun) }\end{array}$ \\
\hline SUA-5/3 & $1090 \pm 60$ & R2671 / 1 & $1045 \pm 40$ & $\begin{array}{l}\text { Rafter (pers } \\
\text { commun) }\end{array}$ \\
\hline SUA-14/6 & $21,400 \pm 500$ & ANU-918 & $23,290 \pm 560$ & $\begin{array}{l}\text { Polach (pers } \\
\text { commun) }\end{array}$ \\
\hline
\end{tabular}

\section{SAMPLE DESCRIPTIONS}

I. ARCHAEOLOGIC SAMPLES

\section{Hooka Point series}

\section{A. Australia}

Samples coll by J P White, Dept Anthropol, Univ Sydney, and R J Lampert, Dept Prehistory, Research School of Pacific Studies, Australian Natl Univ, Canberra, from lakeside aboriginal midden, Hooka Point, Lake Illawarra NSW ( $\left.34^{\circ} 30^{\prime} \mathrm{S}, 150^{\circ} 51^{\prime} \mathrm{E}\right)$.

SUA-66/1. AM 19/1

$2920 \pm 90$

Shell (largely Anadara trapezia) from $10 \mathrm{~cm}$ depth.

$$
970 \text { BC }
$$

\section{SUA-109/1. AM 28/1}

$1440 \pm 95$

Carbonized wood, depth $30 \mathrm{~cm}$.

\section{AD 510}


SUA-66/2. AM 19/2

$3480 \pm 90$

Shell as above, depth $43 \mathrm{~cm}$. $1530 \mathrm{BC}$

SUA-66/3. AM 19/3

$3240 \pm 85$

Shell as above, depth 65 to $75 \mathrm{~cm}$.

$1290 \mathrm{BC}$

\section{SUA-66/4. AM 19/4}

$3675 \pm 85$

1725 BC

Shell as above, depth $80 \mathrm{~cm}$.

$3495 \pm 85$

SUA-180. AM 18/3

1545 BC

Shell as above, depth 95 to $100 \mathrm{~cm}$.

\section{SUA-109/2. AM 28/4}

$2735 \pm 100$

\section{5 вC}

Carbonized wood, depth 105 to $110 \mathrm{~cm}$. Comment (JPW): site completely reworked by natural agencies (Emmerson, 1973; Hughes \& Sullivan, 1974). Thus determinations cannot be related to phases of human occupation. Report filed with NSW Dept Natl Parks \&. Wildlife Service. Sample code refers to sq $\mathrm{m}$ number and excavation unit.

\section{Richmond River series}

Samples coll 1972 by G N Bailey, Dept Archaeol, Cambridge Univ, from area of Richmond R, NSW.

Chiciba Creek $\left(28^{\circ} 51^{\prime} \mathrm{S}, 153^{\circ} 34^{\prime} 36^{\prime \prime} \mathrm{E}\right)$

Site was a partially destroyed shell mound on S bank of creek containing mostly oyster shells (Crassostrea commercialis), also stone artifacts and bone remains of fish and small marsupials. Samples were obtained from excavation of a trench $1 \mathrm{~m}^{2} \times 2 \mathrm{~m}$ deep.

SUA-122. C10 L1S1

$$
880 \pm 85
$$

AD 1070

Fragments of wood charcoal from ca $160 \mathrm{~cm}$ above base of mound.

\section{SUA-123. C11 L4S1}

$$
1410 \pm 100
$$

$$
\text { AD } 540
$$

Fragments of wood charcoal from ca $85 \mathrm{~cm}$ above base of mound.

\section{SUA-124. C12 L6S5}

$$
1700 \pm 90
$$

\section{AD 250}

Dispersed fragments of wood charcoal from ca $6 \mathrm{~cm}$ above base of mound. Site was in use by aborigines ca AD 1850 (Ainsworth, 1922) shortly before replacement of traditional subsistence patterns by European exploitation. Date is approximate terminus ante quem for cessation of shell accumulation. 
North Creek $\left(28^{\circ} 51^{\prime} 12^{\prime \prime} S, 153^{\circ} 34^{\prime} 36^{\prime \prime} E\right)$

Mound of oyster shells on $\mathrm{E}$ bank of creek just $\mathrm{N}$ of road bridge. Site now almost completely destroyed. Bone remains and stone artifacts reported in 19th century with original dimensions of mound (Statham, 1892).

SUA-125. C-21

$1350 \pm 130$

Dispersed fragments of charcoal coll through depth ca $60 \mathrm{~cm}$ of deposit, representing base of mound.

\section{Embley River series}

Samples coll by G N Bailey, Dept Archaeol, Cambridge Univ, from Kwamter, Weipa, Queensland (12 $\left.44^{\prime} \mathrm{S}, 141^{\circ} 55^{\prime} 42^{\prime \prime} \mathrm{E}\right)$. A large shell mound behind mangroves on $\mathrm{S}$ bank of Embley $\mathrm{R}$ near its junction with Hey R, containing mostly cockle shells (Anadara granosa), also stone and bone artifacts and bone remains of fish and small marsupials. Samples were obtained from excavation of trench $1 \mathrm{~m}^{2} \times 3 \mathrm{~m}$ deep.

\section{SUA-147. Weipa Spit-2}

Wood charcoal from $265 \mathrm{~cm}$ above base of mound.

\section{SUA-148. Weipa Spit-13}

Wood charcoal from $150 \mathrm{~cm}$ above base of mound.

\section{SUA-149. Weipa Spit-20}

Wood charcoal from $5 \mathrm{~cm}$ above base of mound.

\section{$710 \pm 100$ AD 1240}

\section{$855 \pm 80$ AD 1095}

$$
\begin{array}{r}
1180 \pm 80 \\
\text { AD } 770
\end{array}
$$

General Comment (GNB): earlier excavation of same site (Wright, 197l) yielded ${ }^{14} \mathrm{C}$ dates as follows:
I-1737. Provenance near top of mound, and

$$
\begin{aligned}
& 235 \pm 110 \mathrm{BP} \\
& 810 \pm 65 \mathrm{BP}
\end{aligned}
$$

\section{I-1738. Provenance at base of mound}

All samples in above 2 series were coll as part of study into prehistoric economies assoc with their formation. The Richmond $\mathrm{R}$ dates were pub with preliminary interpretation by Bailey (1975). Both series date accumulation rate of midden deposit and earliest human occupation in each area.

\section{Blue Mountains series}

Samples coll Aug-Oct 1972 by E Stockton, St Patricks Coll, Manly, NSW, 2095 Australia, as part of study of aboriginal occupation of Blue Mts area of NSW. 
Samples from a rock shelter on King's Tableland, Wentworth Falls, NSIV $\left(33^{\circ} 44^{\prime} S, 150^{\circ} 22^{\prime} E\right)$.

\section{SUA-155. Blue Mts 5}

$965 \pm 75$

Charcoal from Level 5, 23 to $25 \mathrm{~cm}$ below surface. AD 985

SUA-156. Blue Mts 13

Charcoal from Level 13,61 to $66 \mathrm{~cm}$ below surface.

Modern

SUA-229. Blue Mts 15

$1110 \pm 80$

Charcoal from Level 15, 71 to $76 \mathrm{~cm}$ below surface.

\section{SUA-157. Blue Mts 16}

$1060 \pm 115$

Charcoal from Level 16,76 to $84 \mathrm{~cm}$ below surface. AD 890

\section{SUA-194. Blue Mts 19}

$14,500 \pm 580$

$12,550 \mathrm{BC}$

Charcoal from Level 19, 100 to $110 \mathrm{~cm}$ below surface.

$22,300 \pm 1900$

20,350 BC

\section{SUA-158. Blue Mts 21}

$595 \pm 85$

AD 1355

SUA-204. Wa II $20 \mathrm{~cm}$

Charcoal from depth $20 \mathrm{~cm}$, Phase II, Level 5 .

SUA-205. Wa $90-95$

Charcoal from depth 90 to $100 \mathrm{~cm}$, Phase VI.

SUA-206. Wa 140

Charcoal from depth 112 to $120 \mathrm{~cm}$, Phase VI.

SUA-285. W130-140

Charcoal from depth 130 to $140 \mathrm{~cm}$, Phase VI.
$7420 \pm 140$

5470 BC

$7440 \pm 140$

5490 BC

$8565 \pm 430$

$6615 \mathrm{BC}$ 
Other dates in this series, SUA-15-18, have been pub (Gillespie, Polach, \& Temple, 1972).

General Comments: (ES) samples from depth 36 to $44 \mathrm{~cm}$ and above were assoc with Bondaian artifacts, 68 to $76 \mathrm{~cm}$ and below with Capertian.

Like other Blue Mts sites, this one shows a marked break in aboriginal occupation between Bondaian and Capertian periods, suggesting deteriorating climate in intervening period.

\section{East Alligator River series}

Samples coll 1972 and 1973 by $\mathrm{H}$ Allen and J Kamminga, Univ Auckland, Univ Sydney, respectively, during archaeol survey of Alligator $\mathrm{R}$ Environmental Fact-Finding Study. Rock shelters test excavated were located along the escarpment of rock outliers near $E$ Alligator $R$ in $W$ Arnhem Land.

\section{SUA-163. Ngarradj Warde Djobkeng B-1/1 AD 1405}

$$
545 \pm 90
$$

Charcoal underlying sterile sand at topmost layer at Ngarradj Warde Djobkeng $\left(12^{\circ} 30^{\prime} \mathrm{S}, 132^{\circ} 57^{\prime} \mathrm{E}\right)$ indicates that site was not intensively occupied during recent prehistoric times.

\section{SUA-164- Ngaralj Warde $\quad 3450 \pm 125$}

Charcoal from $75 \mathrm{~cm}$ below surface dates base of shell midden at site. Upper midden layers assoc with fragments of edge-ground axes, rectangular scraper/adzes, stone points, shell artifacts, and bone points.

\section{SUA-225. Ngarradj Warde Djobkeng $B-1 / 7$,}

Charcoal from sandy horizon beneath midden zone at depth interval 115 to $125 \mathrm{~cm}$. Preserved bone in horizon suggests a different exploitative pattern than that practiced later at the site. A fragment of cremated human cranium was directly assoc with dated charcoal.

\section{SUA-165. Ngarradj Warde Djobkeng B-1/10}

$8690 \pm 125$

Charcoal from middle of lowest horizon excavated at above site $175 \mathrm{~cm}$ depth. This sandy, organically sterile layer contained a groundedge axe, utilized and retouched flakes, and pieces of ocher, for which this determination gives a median age.

\section{SUA-263. Malakunanja II DJAW-3/4}

$450 \pm 80$

Charcoal from a burial pit excavated into top of midden at this site, located along edge of Djawumba massif $\left(12^{\circ} 29^{\prime} \mathrm{S}, 132^{\circ} 53^{\prime} \mathrm{E}\right)$. Pit contained cremated remains of a single human.

SUA-264. Malakunanja II DJAW-3/7, 8

Charcoal from base of midden deposit at depth 65 to $68 \mathrm{~cm}$ in above site. Midden is rich in bone and estuarine shell. 


\section{SUA-265. Malakunanja II DJAW-3/19}

Charcoal from depth interval 188 to $215 \mathrm{~cm}$ provides earliest evidence of human occupation at above site and is assoc with heavy mortars, the earliest known occurrence of these artifacts in Australia.

\section{Nourlangie Rock series}

Samples coll Nov 1972 by $\mathrm{H}$ Allen, from rock shelters with occupation deposit, at Nourlangie Rock, W Arnhem Land.

SUA-161. Nangalu-uru NOU-6/3

$755 \pm 125$ AD 1195

Charcoal from Nangalu-uru $\left(12^{\circ} 52^{\prime} \mathrm{S}, 132^{\circ} 53^{\prime} \mathrm{E}\right)$, from depth $20 \mathrm{~cm}$ assoc with utilized flakes and scrapers typical of recent prehistoric phase.

\section{SUA-226. Burial cave NOU-1/2}

Charcoal from burial cave $\left(12^{\circ} 54^{\prime} \mathrm{S}, 132^{\circ} 48^{\prime} \mathrm{E}\right)$, from midden deposit assoc with scrapers, utilized flakes, and bifacial and unifacial points.

\section{SUA-162. Burial cave NOU-1/7}

$8625 \pm 550$

Charcoal from depth $80 \mathrm{~cm}$ assoc with earliest stone tools found in test excavation at this site.

\section{Deaf Adder Gorge series}

Samples coll June 1973 by J Kamminga, Dept Anthropol, Univ Sydney, from rock shelters in Deaf Adder Gorge, W Arnhem Land.

\section{SUA-243. Leichhardt site DA-1/9}

$2130 \pm 55$

Charcoal from Spit 9 at depth interval of 40 to $45 \mathrm{~cm}$ in test trench at Leichhardt site, a well known aboriginal art site $\left(13^{\circ} 02^{\prime} \mathrm{S}, 132^{\circ}\right.$ $\left.59^{\prime} \mathrm{E}\right)$. Spit is midway within occupational deposit at site and its date suggests that deposit is undisturbed.

\section{SUA-244. Leichhardt site DA-1/14-16}

$5045 \pm 125$ 3095 BC

Charcoal from spits at 70 to $90 \mathrm{~cm}$ depth. Earliest evidence of occupation at site. Date of stone technology recovered here corresponds with other dated 'Upper Phase' industries in W Arnhem Land.

\section{SUA-235. Lindner site DA-4/9}

$$
3070 \pm 85
$$

Charcoal from spit at depth interval 40 to $45 \mathrm{~cm}$ in test excavation at this site $\left(13^{\circ} 05^{\prime} \mathrm{S}, 132^{\circ} 55^{\prime} 30^{\prime \prime} \mathrm{E}\right)$. Dates earliest bifacial and unifacial stone points in excavation. 
SUA-236. Lindner site DA-4/24, 25

$13,195 \pm 175$

$11,145 \mathrm{BC}$

Charcoal from 2 spits at depth 125 to $130 \mathrm{~cm}$. Dates oldest small rectangular scraper/adzes in excavation, surprisingly early for artifact type considered more typical of later period.

\section{SUA-237. Lindner site DA-4/32-35}

$19,975 \pm 365$ $18,025 \mathrm{BC}$

Charcoal from basal levels of occupational sediment assoc with quartz scalar cores and a quartzite horsehoof core (Kamminga \& Allen, 1973).

\section{Swansea Channel series}

These 2 samples coll by $\mathrm{L} \mathrm{K}$ Dyall, Univ Newcastle, from an aboriginal midden $\left(33^{\circ} 6^{\prime} \mathrm{S}, 151^{\circ} 40^{\prime} \mathrm{E}\right) 13 \mathrm{~m}$ above shoreline of channel between Lake Macquarie and the Pacific Ocean. Midden is adjacent to both estuarine and headland ecology and contains extensive faunal remains of an economy based on fishing and collecting shellfish, but appreciably augmented by hunting. Stone and bone implements were manufactured on site, also used as a burial site.

\section{SUA-238. Swanch-2}

$1965 \pm 85$

Charcoal from compacted shell surface. Date is consistent with reports of European burning of these middens to obtain lime in 19th century. More recent material was dug away.

\section{SUA-150. Swanch-1}

$7870 \pm 115$

5920 вC

Charcoal from lowest occupation, 44 to $49 \mathrm{~cm}$ depth, some $10 \mathrm{~cm}$ below intensive occupation layer. This earliest occupation, evidenced by a thin scatter of stone flakes and burned bone in gravelly sand is very early for a coastal midden.

\section{Devil's Lair series}

Samples coll by C E Dortch, D Merrilees et al as part of continuing studies of aboriginal occupation of a small limestone cave in extreme SW Western Australia $\left(34^{\circ} 09^{\prime} \mathrm{S}, 115^{\circ} 04^{\prime} \mathrm{E}\right)$. Previous dates reported by Dortch and Merrilees (1973).

\section{SUA-342.}

Charcoal from Trench $7 \mathrm{~b}$ uppermost of major stratigraphic units. Date consistent with field observation that this unit very young. No assoc artifacts or faunal remains.

\section{SUA-364.}

$6490 \pm 145$

Charcoal from Trench $7 \mathrm{c}$ from sandy pocket between 2 crystalline flowstones near top of sediment. Artifacts and animal remains are also present. 
Northcliffe samples

SUA-379. KS-2

$6780 \pm 120$

4830 вс

Date is based on charcoal from a $10 \mathrm{~cm}$ artificial layer in lower part of leached or pallid zone of podsolized sands partly overlying a forma-

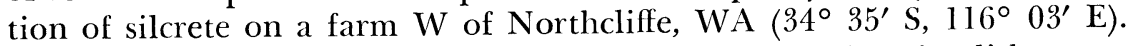
Site was a silcrete quarry and factory where geometric microliths were manufactured in quantity. SUA-379, from depth 85 to $95 \mathrm{~cm}$ below datum, and ANU-1131, $3080 \pm 75 \mathrm{yr}$ вP, from depth $50 \mathrm{~cm}$ below datum, bracket a stone industrial sequence containing geometric microliths, blades, bladelets, and quantities of flakes, chips, and fragments almost all of which are made of local silcrete. The lowermost geometric microlith occurs 1 to $3 \mathrm{~cm}$ above uppermost charcoal sampled for SUA-379. Pollen samples from same position as ANU-1131 and from below SUA-379 contain pollen grains of Eucalyptus diversicolor, E calophylla, and E marginata, species which are presently dominant in the area.

Southeastern Tasmania

$$
\text { II. GEOLOGIC SAMPLES }
$$

A. Australia

Samples coll by E A Colhoun, Dept Geog, Univ Tasmania.

\section{Pipeclay Lagoon}

$\left(42^{\circ} 55^{\prime} \mathrm{S}, 147^{\circ} 34^{\prime} \mathrm{E}\right)$

$25,380 \pm 640$

SUA-151. No. 1

24,430 BC HWST.

Dark brown organic rich marine clay from 31 to $36 \mathrm{~cm}$ above present

SUA-152. No. 2

As above, 39 to $44 \mathrm{~cm}$ above present HWST.

SUA-153. No. 3

As above, 52 to $56 \mathrm{~cm}$ above present HWST.

SUA-153/2.

General Comment (EAC): 1st 3 samples were from beds of highly humified to moderately humified organic sandy clay in eroded cliff sec on SE side of Lagoon. Clay is underlain by marine sandy clays of presumed last Interglacial age and overlain by strongly podsolized aeolian sands. 1 st 3 assays suggest that organic sediments were deposited at base of a deflation hollow formed ca 25,000 to $20,000 \mathrm{yr}$ BP during last Glacial Stage.

\section{Macquarie Island}

Samples coll by E A Colhoun and A Goede, Nov, 1972 on Macquarie I $\left(54^{\circ} 38^{\prime} \mathrm{S}, 158^{\circ} 55^{\prime} \mathrm{E}\right)$. 


\section{SUA-178. Macquarie Island-1}

Peat with numerous plant debris from Green Gorge, Macquarie I.

\section{SUA-179. Macquarie Island-3}

Peat from Bauer Bay, Macquarie $I$. in stream valley $400 \mathrm{~m} \mathrm{~N}$ of ANARE hut.

Comment (EAC): these 2 samples are from base of peat overlying highest marine sediments found at Green Gorge and Bauer Bay. Results suggest that tectonic elev exposed extensive marine terrace of Macquarie I mainly during last $2000 \mathrm{yr}$. Rate of uplift $>1.5 \mathrm{~m} / 1000 \mathrm{yr}$ and $<4.5 \mathrm{~m} /$ $1000 \mathrm{yr}$ (Colhoun and Goede, 1974).

\section{Point Waylen series}

Samples coll by G W Kendrick, West Australian Mus from Point Waylen, WA (31 $\left.1^{\prime} 3^{\prime \prime} \mathrm{S}, 115^{\circ} 48^{\prime} 35^{\prime \prime} \mathrm{E}\right)$.

\section{SUA-339.}

$4500 \pm 100$

Shell (Circe sulcata sp) 20 to $30 \mathrm{~cm}$ below surface in pale brown quartz sand with abundant mollusk shells.

SUA-340.

As above, 60 to $70 \mathrm{~cm}$ below surface.

SUA-341.

Shell (Sanguinolaria biradiata) 100 to $120 \mathrm{~cm}$ below surface in dark gray mud with abundant mollusk shells.

General Comment (GWK): dates confirm Middle Holocene age of emergent sediment marginal to Swan R. Sequence shows abrupt transition from shallow basin to marginal sand-sill facies in a sheltered marine embayment of approx normal salinity, in contrast to modern hydrologic condition of estuary. Youngest dated sample came from 10 to $20 \mathrm{~cm}$ above mean sea level and top of shell bed lies $5 \mathrm{~cm}$ above.

Northcliffe sample

SUA-343.

$8335 \pm 130$

6385 вC

Wood from tree stump apparently in situ on ocean beach near mean sea level on S coast of Western Australia W of Northcliffe $\left(34^{\circ} 38^{\prime} \mathrm{S}\right.$, $115^{\circ} 52^{\prime} \mathrm{E}$ ). Coll by $\mathrm{N}$ Marchant, D Merrilees et al, W A Mus, and still under study by N M and D M (Dortch and Merrilees, 1973).

\section{King River series}

Samples coll by B G Thom, Dept Biogeog \& Geomorphol, Australian Natl Univ below a high-tidal flat on the King R near Wyndham, Western Australia $\left(15^{\circ} 25^{\prime} \mathrm{S}, 128^{\circ} 05^{\prime} \mathrm{E}\right)$. 
SUA-30B. T1

$6720 \pm 110$

Organic mud assoc with SUA-30A (Gillespie and Temple, 1973). Comment (BGT): samples date buried organic surface 3 to $4 \mathrm{~m}$ below present surface. Age was cross-checked by ANU-1091, $6200 \pm 260$, on wooden fragments from another site. Sea level at this time in this hightide range was probably 2 to $3 \mathrm{~m}$ below present (Thom and Chappell, 1975).

\section{Gold Coast series}

Samples coll by B G Thom from below sea level off Gold Coast, Queensland $\left(28^{\circ} 05^{\prime} \mathrm{S}, 153^{\circ} 15^{\prime} \mathrm{E}\right)$.

\section{SUA-105. Palm Beach Reef 3}

$980 \pm 80$

Shell fragments.

\section{SUA-106. ETA 20 4/6}

$10,560 \pm 160$

8610 BC

Peat. Comment (BGT): SUA-105 reflects relatively modern production of carbonate at least to water depths of 12 to $13 \mathrm{~m}$. SUA-106 represents fresh water (?) peat under a veneer of sand. Sea level must have been below $-26 \mathrm{~m}$ when peat was deposited (Thom and Chappell, 1975).

\section{Port Stephens-Myall Lakes series}

Samples coll by B G Thom, from below the Outer Barrier in the Newcastle Bight embayment, New South Wales.

SUA-104. T3-T4

$9000 \pm 230$

Mixed shell fragments coll by L Bennett from Stockton, New South Wales $\left(32^{\circ} 52^{\prime} \mathrm{S}, 151^{\circ} 49^{\prime} \mathrm{E}\right)$.

SUA-248. $\quad 53-10$

$5820 \pm 115$

3870 BC

Mixed shell and sand fragments from Anna Bay near Newcastle, New South Wales $\left(32^{\circ} 47^{\prime} \mathrm{S}, 152^{\circ} 04^{\prime} \mathrm{E}\right)$.

SUA-249. 53-27

Mixed shell and sand fragments from above location.

SUA-253. $\quad 52-13$

$16,280 \pm 360$

Mixed shell and sand fragments from above location.

SUA-251. D1

Charcoal from Eurunderee near Seal Rocks, New South Wales $\left(32^{\circ}\right.$ $\left.29^{\prime} \mathrm{S}, 152^{\circ} 23^{\prime} \mathrm{E}\right)$. 
SUA-252. $\quad \mathbf{5 7 - 7}$

Organic fibers from above location.

SUA-246. $50-13$

Organic clay from Salamander Bay near Newcastle, New South Wales $\left(32^{\circ} 45^{\prime} \mathrm{S}, 152^{\circ} 06^{\prime} \mathrm{E}\right)$.

\section{SUA-247. 52-4}

Peat from Anna Bay, near Newcastle, New South Wales $\left(32^{\circ} 45^{\prime} \mathrm{S}\right.$, $\left.152^{\circ} 07^{\prime} \mathrm{E}\right)$.

SUA-250. $55-11$

Organic sand from Eurunderee, near Seal Rocks, New South Wales $\left(32^{\circ} 29^{\prime} \mathrm{S}, 152^{\circ} 23^{\prime} \mathrm{E}\right)$.

\section{SUA-254. B1}

Shells (Anadara sp) from Largs, near Maitland, New South Wales $\left(32^{\circ} 45^{\prime} \mathrm{S}, 151^{\circ} 33^{\prime} \mathrm{E}\right)$.

General Comment (BGT): SUA-104 dates transgressive facies of Outer Barrier; shells were probably living on sea line close to time of deposition. But SUA-253, from the same facies, reflects either landward transport of biogenic carbonate with the marine transgression and/or incorporation of eroded Inner Barrier shells during the transgression. SUA. 249 is date on Inner Barrier near shore; shelly sands probably assoc with last Interglacial period, са 120,000 BP. SUA-251, -252 dates are maximum of transgressive dune sheets with buried soils containing organic material. Samples SUA-246, -247, -250 represent organic-rich materials recovered by drilling below well-podsolized surfaces; dating "beyond the range" of ${ }^{14} \mathrm{C}$, thus, establishes antiquity of assoc deposits. Background age for SUA-254 confirms earlier dating by Thom (1965).

\section{Mt Carstensz (Jaya) series}

$$
\text { B. West Irian }
$$

Samples coll Jan 1972 from Yellow Valley, $4250 \mathrm{~m}$ alt near Mt Carstensz, Irian Jaya, Western New Guinea $\left(4^{\circ} 05^{\prime} \mathrm{S}, 137^{\circ} 09^{\prime} \mathrm{E}\right)$ by $\mathrm{J}$ Peterson and $\mathrm{G}$ Hope, Biogeog Dept, Australian Natl Univ.

SUA-19. CGE-1

$2470 \pm 80$

Peat from above deformed lake sediments and beneath till.

SUA-20/1. CGE-2

Peaty soil from same site, including rootlets.

SUA-20/2. CGE-2

As above, organic fines only.
$1400 \pm 80$ AD 550

$2930 \pm 100$ 980 BC 


\section{SUA-177. CGE-11}

$1520 \pm 105$

Lake sediment containing organic matter.

\section{SUA-216. CARS-P3}

Peat.

\section{SUA-217. CARS-P5}

$1335 \pm 80$

Wood fragments from buried peaty soil.

General Comment (GSH): above dates from organic matter buried beneath neoglacial tills and reflect glacier retreat above $4250 \mathrm{~m}$. Minor ice advances predate SUA-20/2, occur twice between SUA-19 and -177 and again after -217 . One of best-dated neoglacial ice advance sequences in the world.

\section{Discovery Valley series}

Coll by $\mathrm{J} P$ and $\mathrm{G}$ H from Ijomba Core, Discovery Valley, alt $3580 \mathrm{~m}\left(4^{\circ} 02^{\prime} \mathrm{S}, 137^{\circ} 13^{\prime} \mathrm{E}\right)$.

\section{SUA-107. CGE-5}

$13,850 \pm 260$

Algal gyttja deposited in fresh water.

\section{$11,900 \mathrm{BC}$}

\section{SUA-108. CGE-6}

$6450 \pm 100$

As above.

General Comment (GSH): 2 samples are from a pollen-analyzed core of sediments from a moraine-dammed lake. SUA-107 gives minimal deglaciation from Pleistocene ice advances, while SUA-108 records arrival of shallow water phase preceding in-filling. Oldest minimal glaciation date for New Guinea. Pollen analysis from SUA-107 horizon records conditions similar to present.

\section{Aghawagon Valley series}

Coll by J P and G H from Erztberg Mines, Aghawagon Valley, alt $3620 \mathrm{~m}\left(4^{\circ} 04^{\prime} \mathrm{S}, 137^{\circ} 07^{\prime} \mathrm{E}\right)$.

\section{SUA-29A. CGE-4A}

$11,330 \pm 150$

9380 BC till.

Woody fragments from peat between weathered bedrock and glacial

SUA-29B. CGE-4B

$11,820 \pm 150$

Fine organic mud from above sample.

SUA-174A. CGE-8A

$13,260 \pm 195$

Algal gyttja buried under till.

\section{$11,310 \mathrm{BC}$}


SUA-175. CGE-9

Organic soil buried under 5 to $10 \mathrm{~m}$ till.

\section{SUA-176A. CGE-10A} till.

Wood (twigs, stem, and bark) from above, buried under $4 \mathrm{~m}$ barren
$11,810 \pm 250$

9860 BC

$5830 \pm 540$

3880 вC

\section{SUA-176B. CGE-10B}

$7510 \pm 110$

Peat assoc with above sample.

5560 BC

General Comment (GSH): dates mark retreat of Pleistocene ice above site, with readvance after SUA-174A and again after $-29 \mathrm{~A}$ and -175 . Sequence records fluctuations in Pleistocene ice retreat for lst time in New Guinea, but general age for retreat accords with dates elsewhere in New Guinea and tropics. SUA-176A is wood in a mudslide; age is minimum for return to present conditions.

\section{SUA-173. CGE-7}

$3745 \pm 95$

$1795 \mathrm{BC}$

Wood enclosed in a large till-like valley deposit, thus providing maximum age for mudflow, Aghawagon Valley, alt $1820 \mathrm{~m}\left(4^{\circ} 07^{\prime} \mathrm{S}\right.$, $\left.137^{\circ} 05^{\prime} \mathrm{E}\right)$.

\section{SUA-28A. CGE-3}

$$
10,100 \pm 130
$$

$\mathrm{NaOH}$-insoluble portion of wood from $\log$ overridden by till, Aghawagon Valley, alt $1705 \mathrm{~m}\left(4^{\circ} 08^{\prime} \mathrm{S}, 137^{\circ} 05^{\prime} \mathrm{E}\right)$.

\section{SUA-28B. CGE-3}

$10,540 \pm 130$

$\mathbf{8 5 9 0} \mathbf{~ B C}$
$\mathrm{NaOH}$-soluble (humic acid) fraction of above. Comment: 2 samples were from wood crushed beneath till-like deposit; date is maximum for either a mudflow or till deposition. Pollen analysis indicates cooler conditions than, or similar to present. Refs to dates and relevant comparable dates in New Guinea included in Hope and Peterson (1975).

\section{Errata :}

Devils Lair series, R, 1973, v 15, p 567-568. Depths given refer to an arbitrary mark on a vertical cave wall, not to a "surface datum."

Description on SUA-101 should read: $201-212 \mathrm{~cm}$, base of "first orange brown earthy layer". Omitted sample:

\section{SUA-33. Devil's Lair C}

$19,250 \pm 900$

From Trench $5,222 \mathrm{~cm}$ 17,300 BC layer". From a triangular layer of a thin flowstone, in "light earthy For SUA-32, Trench no. (2) was omitted.

General Comment contains phrase: "considerably old", which did not originate from D.M. 


\section{REFERENCES}

Ainsworth, J, 1922, Reminiscences: 1847-1922, Ballina, NSW.

Bailey, G N, 1975, The role of molluscs in coastal economies; the results of midden analysis in Australia: Jour Archaeol Sci, v 2, p 45-62.

政 $\mathrm{C}$ dates and the raised marine terraces of Macquarie Island: some comments: Search, v 4, p 499-501

Dortch, C E and Merrilees, E, 1973, Human occupation of Devil's Lair Western Australia, during the Pleistocene: Archaeol and Phys Anthropol in Oceania, v 8, p 89-115.

Emmerson, P, 1973, A disturbed site: unpub BA thesis, Dept Anthropol, Univ Sydney. Gillespie, R, Polach, $\mathrm{H} \mathrm{A}$, and Temple, R B, 1972, Sydney University natural radiocarbon measurements I: Radiocarbon, $v$ 14, p 413-417.

Gillespie, R and Temple, R B, 1973, Sydney University natural radiocarbon measurements II: Radiocarbon, v 15, p 566-573.

Hope, G S and Peterson, J A, 1975, Glaciation and vegetation in the high New Guinea Mountains: Royal Soc New Zealand Bull, v 13, in press.

Hughes, P J and Sullivan, M E, 1974, The re-deposition of midden material by storm waves: Jour Royal Soc New South Wales, Proc, v 107, p 6-10.

Kamminga, J and Allen, H R, 1973, The Alligator Rivers environmental fact-finding study: Rept archacol survey. Dept $N$ Terr \& Australian Mining Ind Council, Darwin, N Terr, Australia.

Polach H A 1969, Optimization of liquid scintillation radiocarbon age determinations and reporting of ages: Atomic Energy in Australia, v 12, no. 3, p 15-23.

Statham, E J, 1892, Observations of shell-heaps and shell-beds: Jour Royal Soc New South Wales, v 26, p 304-314.

Stockton, E and Holland, W N, 1974, Cultural sites and their environment in the Blue Mts: Archaeol and Phys Anthropol in Oceania, v 9, p 36-65

The Port Stephens-Myal Lakes area, New South Wales: Jour Royal Soc New South Wales, v 98, p 23-36.

Thom, B G and Chappell, J, 1975, Holocene sea levels relative to Australia: Search, v 6, p 90-93.

Thom, B G, Wright, L D, and Coleman, J M, 1975, Mangrove ecology and deltaic estuarine geomorphology, Cambridge Gulf-Ord River, Western Australia: Jour Ecol, v 63, p 203-232.

Wright, R V S, 1971, Prehistory in the Cape York Peninsular, in: Mulvaney, D J and Golson, J (eds), Aboriginal man and environment in Australia, Canberra: Australian Natl Univ Press, p 133-140. 